\title{
OCCURRENCE AND MATURATION OF RHABDOCHONA GNEDINI (NEMATODA: RHABDOCHONIDAE) IN THE BARBELS OF THE SOUSA RIVER, PORTUGAL
}

\author{
SARAIVA A.*, FELISBERTO P.* \& CRUZ C.*
}

\section{Summary :}

Data on the seasonal occurrence and maturation of Rhabdochona gnedini Skrjabin, 1946 in its definitive host, the barbel Barbus bocagei, from the Sousa River, in northern Portugal, are presented. Monthly samples were taken from November, 1998 to October, 1999. A total of 178 fish specimens were inspected. R. gnedini occurred with high prevalences during whole year, attaining the highest values of intensity in summer loverall prevalence and mean intensity $85 \%$ and 31 , respectively). A clear annual cycle of maturation was observed; females with mature eggs occurred in spring and summer. Unidentified Rhabdochona larvae were recorded from the trichopteran larvae Hydropsyche sp. (prevalence and intensity $29 \%$ and one to 34 , respectively). These larvae are presumptive intermediate host for R. gnedini.

KEY WORDS : Rhabdochona gnedini, Nematoda, Barbus bocagei, barbel, occurrence, maturation, Portugal.

T The genus Rhabdochona Railliet, 1916 includes a large number of species that are parasites of freshwater fishes of nearly whole world (Moravec, 1975).

Of the nine species of Rhabdochona that occur in Europe (Moravec, 1994), only four have been reported from freshwater fishes from the Iberian Peninsula: $R$. anguillae Spaul, 1927 from Anguilla anguilla from Portugal and Spain; $R$. denudata (Dujardin, 1845) from Leuciscus cephalus, Chondrostoma polylepis and Rutilus arcasii from Spain; $R$. gnedini Skrjabin, 1946 from Barbus bocagei and Salmo trutta m. fario (reported as R. sulaki (Saidov, 1953)) from Spain, and $R$. hellichi (Šrámek, 1901) from Barbus meridionalis from Spain (Cordero del Campillo et al., 1994). In Europe, $R$. gnedini and $R$. hellichi parasitize mainly Barbus spp.

The life cycle of $R$. gnedini is not known and that of $R$. hellichi is insufficiently known. According to Moravec (1995), $R$. hellich $i$ is the only known $R h a b$ -

\footnotetext{
* Departamento de Zoologia e Antropologia, Faculdade de Ciências, Universidade do Porto, Praça Gomes Teixeira, 4099-002 Porto, Portugal.

Correspondence: A.M. Saraiva.

Tel.: ++351223401400 - Fax : ++351223401511.

E-mail: amsaraiv@fc.up.pt
}

Résumé : PRÉvalence, INTENSITÉ SAISONNIÈRE ET MATURATION DE RHABDOCONA GNEDINI (NEMATODA : RHABDOCHONIDAE) CHEZ LE Barbeau du fleuve SOUSA, AU PORTUGal

Des données mensuelles sur la prévalence et l'intensité saisonnière, ainsi que sur la maturation du Nématode Rhabdocona gnedini Skrjabin, 1946, parasite de Barbus bocagei 1178 spécimens récoltés) ont été répertoriées de novembre 1998 à octobre 1999 dans le fleuve Sousa, au nord du Portugal. Le parasite, présent toute l'année avec une prévalence très élevée, a une intensité maximale en été. La prévalence et l'intensité moyenne totale sont de 85 et $31 \%$, respectivement. Le cycle de maturation annuelle est bien marqué, les femelles avec des œufs mûrs étant présentes au printemps et en été. Des larves de Rhabdocona sp. ont été retrouvées chez des larves de Trichoptera Hydropsyche spp. Ces larves pourraient être des hôtes intermédiaires de R. gnedini.

MOTS CLÉS : Rhabdochona gnedini, Nematoda, Barbus bocagei, barbeau, occurrence, maturation, Portugal.

dochona species that has caddis fly larvae (Trichoptera) of the genus Hydropsyche as intermediate hosts. As the knowledge about the biology of $R$. gnedini is scarce and this nematode is an abundant parasite of barbels from the Sousa River, a study on its seasonal occurrence and maturation, and on the presumptive intermediate host was carried out.

\section{MATERIALS AND METHODS}

The population dynamics of $R$. gnedini was followed in barbels from the lowest reaches of the 1 Sousa River, a tributary of the Douro River, from the locality of Senhora do Salto, situated about $20 \mathrm{~km}$ east of Porto, northern Portugal. Monthly barbel sampling was done by electrofishing from November 1998 to October 1999. A total of 178 specimens (mean total length: $21.6 \pm 6.34 \mathrm{~cm}$ ) were inspected for nematodes.

The parasites were removed from the intestine, washed in saline, fixed in hot $70 \%$ ethanol, stored in $70 \%$ ethanol, and cleared in glycerol for determination of sex and maturity stage.

The sex ratio and the occurrence of females in different stages of development (gravid females with mature 
(larvated) eggs/females in other stages of development) throughout the year were compared by Chi-square test. The intensity of infection throughout the year was compared using the extension of the median test (Siegel \& Castellan, 1989).

Benthic invertebrates were also collected from the same locality from December 1998 to September 1999.

\section{RESULTS}

The prevalence and mean intensity of $R$. gnedini infection in barbels during the study period are shown in Figure 1. R. gnedini was present in barbels during all the year. The total prevalence was $85 \%$. Prevalence was always higher than $50 \%$ and in March, April, July, August and September attained $100 \%$. The total mean intensity of infection was 31 and intensity ranged between 1 and 362. Significant differences in the intensity of infection were found during the year $\left(\chi^{2}=34.72\right.$, d.f. $\left.=11, \mathrm{p}<0.05\right)$. The highest values of mean intensity occurred in August (93) and September (50), and the minimum values in October (4) and November (5). A slight increase in the mean intensity values was noticed in March (32) and April (40).
Adults (males and females) of $R$. gnedini occurred in barbels throughout the year (Fig. 2). Significant differences were found in the proportion of males and females during the year $\left(\chi^{2}=82.75\right.$, d.f. $\left.=11, \mathrm{p}<0.05\right)$. The proportion between females and males was usually higher than one (1:1 to 2:1) but in December was much higher $(5: 1)$. Undifferentiated nematodes occurred throughout the year but in low proportion between March and July (Fig. 2).

The proportion of females in different stages of development (females with mature eggs, females with immature eggs and females without eggs in uteri) during the year are shown in Figure 3. Significant differences were detected in the proportion of females with mature eggs and females in others developmental stages during the year $\left(\chi^{2}=573.81\right.$, d.f. $\left.=11, \mathrm{p}<0.05\right)$. The nematodes exhibited a distinct annual cycle of maturation since females with mature eggs were present only from February to September attaining more than $50 \%$ of females collected in May, June and September. Excluding these months, immature females (without eggs) were present in very high proportions throughout the year, being the only stage of female development observed from October to December (Fig. 3).

Mayfly larvae (Ephemeroptera) of Ecdyonurus dispar (38 specimens) and caddis fly larvae (Trichoptera) of
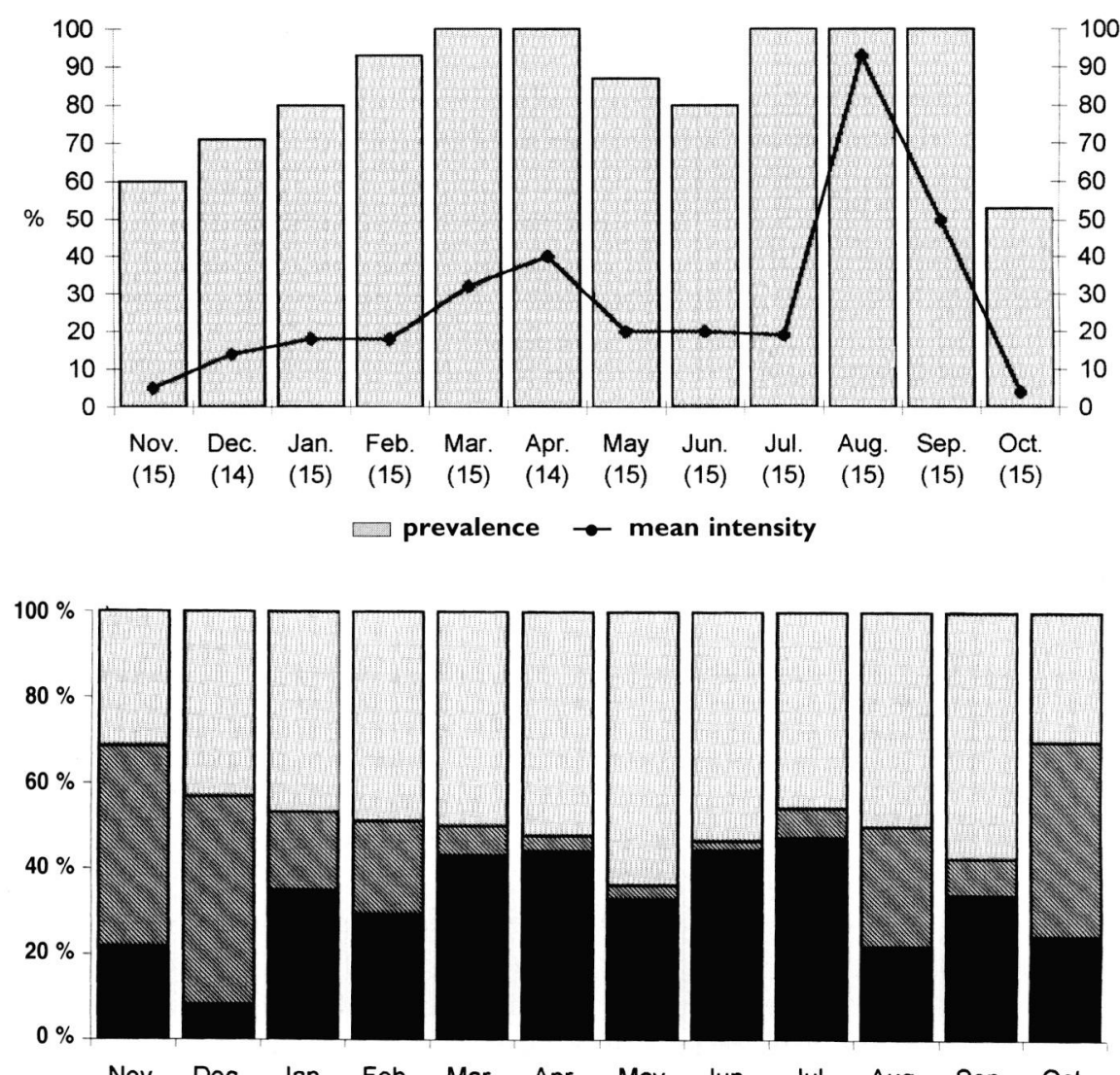

Nov.
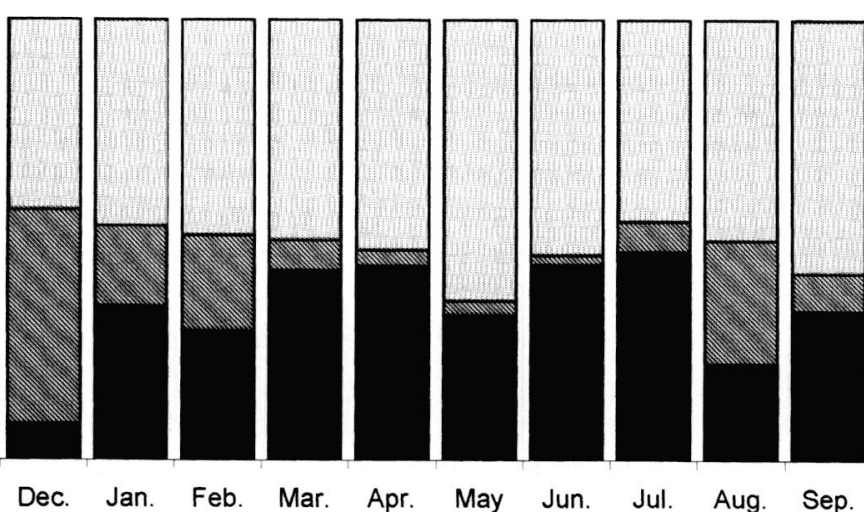

males

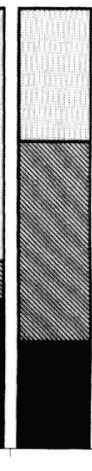

Fig. 1. - Monthly changes in prevalence and mean intensity of Rhabdocona gnedini from barbels from the Sousa River, from November 1998 to October 1999. Sample size in brackets.

Fig. 2. - Monthly changes in the proportions of males, females and undifferentiated nematodes of Rhabdochona gnedini from barbels from the Sousa River from November 1998 to October 1999. 


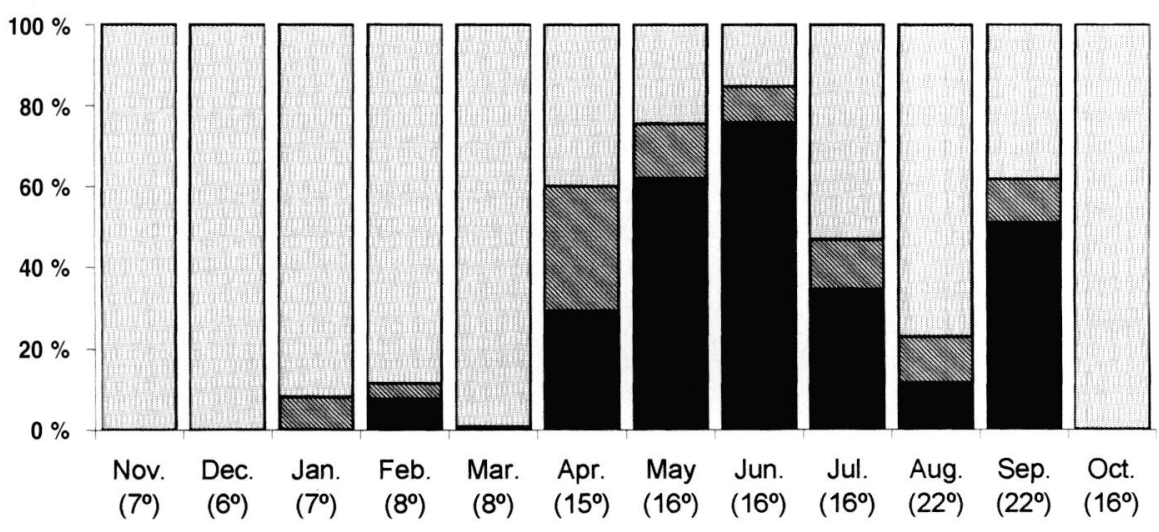

Fig. 3. - Monthly changes in the proportion of females with mature eggs, females with immature eggs and females without eggs of Rhabdochona gnedini from barbels from the Sousa River from November 1998 to October 1999. Water temperature in brackets

females with mature eggs $\square$ females with immature eggs $\square$ females without eggs

Hydropsyche spp. (120 specimens) were examined for the presence of nematode larvae. Rhabdochona larvae were detected only in Hydropsyche spp. larvae (total prevalence $29 \%$, intensity of infection one to 34 ). Infected Hydropsyche spp. larvae were detected from April to August. The nematode larvae were located in the abdomen and thorax of caddies flies spirally coiled inside a capsule. Sometimes more than one nematode larva was observed in a capsule. The two smallest larvae observed had a small straight vestibule, no differentiated prostoma and no teeth being considered, for these reasons, as second stage larvae. All the other nematode larvae were in third or fourth stage. The fourth larval stage was easily distinguished from the third stage due to the presence of distinct basal teeth in the prostom and differentiated sex. Measurements of larvae from Hydropsyche spp. are given in Table I. It must be stressed out that, besides $R$. gnedini, one additional congeneric species, $R$. anguillae, was detected from eels $A$. anguilla (prevalence $54 \%$, mean intensity 3 ) in this locality, so these larvae could not be specifically identified.

\begin{tabular}{lccc}
\hline $\begin{array}{c}\text { Measurements } \\
(\mathrm{mm})\end{array}$ & $\begin{array}{c}\text { Second-stage } \\
\text { larvae }(\mathrm{n}=2)\end{array}$ & $\begin{array}{c}\text { Third-stage } \\
\text { larvae }(\mathrm{n}=14)\end{array}$ & $\begin{array}{c}\text { Fourth-stage } \\
\text { larvae }(\mathrm{n}=4)\end{array}$ \\
\hline $\begin{array}{l}\text { Length of body } \\
\text { Width of body }\end{array}$ & $0.40-0.43$ & $1.47-1.88$ & $\begin{array}{c}2.10-3.72 \\
\text { Length of prostoma }\end{array}$ \\
$0.015-0.018$ & $0.035-0.065$ & $0.055-0.105$ \\
$\begin{array}{l}\text { Width of prostoma } \\
\text { Length of vestibule }\end{array}$ & 0.015 & $0.009-0.011$ & $0.013-0.015$ \\
$\begin{array}{l}\text { Length of muscular } \\
\text { oesophagus }\end{array}$ & $0.085-0.093$ & $0.067-0.009$ & $0.009-0.010$ \\
Length of glandular & & 0.074 & $0.075-0.080$ \\
oesophagus & $0.100-0.154$ & $0.550-0.795$ & $0.150-0.185$ \\
$\begin{array}{l}\text { Distance of nerve } \\
\text { ring from ant. end }\end{array}$ & 0.055 & $0.080-0.091$ & $0.750-1.754$ \\
$\begin{array}{l}\text { Distance of excret. } \\
\text { pore from ant. end }\end{array}$ & 0.050 & $0.050-0.093$ \\
Length of tail & & $0.110-0.138$ & $0.137-0.150$ \\
\hline
\end{tabular}

Table I. - Measurements of Rhabdochona larvae from infected Hydropsyche spp. larvae from the Sousa River.

\section{DISCUSSION}

T $\mathrm{t}$ was found in the present study that $R$. gnedini was present in barbels with high prevalence during the whole year, attaining the highest values of intensity in summer.

As it was repported for $R$. phoxini Moravec, 1968 and R. hellichi (Moravec, 1977; Moravec \& Scholz, 1995), the maturation of $R$. gnedini was found to be strictly seasonal and in all these species females with mature eggs were found only in spring and summer when water temperatures were higher. Pereira Bueno \& Alvarez Pellitero (1979) also reported a well-defined seasonal cycle of maturation of $R$. gnedini in Barbus bocagei in the rivers from Léon, Spain. According to these authors gravid females were present in fish throughout the year but their percentage was higher in spring and summer months and lower in winter months, but it was not clearly reported if the gravid females contained mature or immature eggs.

Although new infections in fish occur throughout the year, as stated by the presence of undifferentiated nematodes in barbels all the year round, new infections seem to be much less frequent from March to July. However, the low number of undifferentiated nematodes in these months may be a result of a fast development of the nematodes under higher water temperatures. The marked peak in intensity observed in August and September and the presence of young $R$. gnedini population present in fish in the following months strongly suggest that new infections were also frequent at that time of the year. According to experimental studies of Moravec (1972, 1976), the development of $R$. ergensi Moravec, 1968 and $R$. phoxini to the infective stage in the intermediate host lasts approximately one month at a water temperature of 13 to $15^{\circ} \mathrm{C}$. As in the study area the water temperature during the reproductive period (April to September) varied between 15 and $22^{\circ} \mathrm{C}$, it may be supposed that $R$. gnedini development in the intermediate 
host lasts less than one month, and the parasite rapidly infects the definitive host.

In the colder autumn and winter months, the development of $R$. gnedini in barbels seems to slow down as $R$. gnedini population is composed mainly of undifferentiated and juvenile specimens. The low proportion value of males observed in December seems to be related with a slightly longer differentiation period of the males as compared to females.

From the nine Rhabdochona species occurring in Europe the life cycle and transmission patterns of only four species are known. In $R$. denudata, $R$. ergensi and $R$. phoxini it was experimentally found that they could develop in mayfly nymphs (Moravec, 1972, 1976, 1977, 1994), while in $R$. bellichi the intermediate hosts are caddis fly larvae of the genus Hydropsyche (Moravec, 1994, 1995).

According to Moravec \& Scholz (1995), the existence of caddis flies as intermediate hosts for $R$. hellichi appears to be an important adaptation of this parasite to the host's ecology, because trichopterans constitute a very important component of barbel's food. According to the same authors the small size of $R$. hellich $i$ eggs is an adaptation to the small size of trichopteran mouth. The size of $R$. gnedini eggs $(0.025-0.030 \times 0.018-$ $0.020 \mathrm{~mm})$ is similar to that one of $R$. hellichi eggs $(0.027-0.036 \times 0.018-0.024 \mathrm{~mm})$ and markedly smaller than $R$. anguillae eggs $(0.041-0.054 \times 0.025-0.030 \mathrm{~mm})$, the only congeneric species recorded from fishes in the studied area.

Although we could not exclude that Hydropsyche spp. larvae could serve as intermediate host of both $R h a b$ dochona species present in the study area, it seems that caddis flies of the genus Hydropsyche serve as the intermediate host of $R$. gnedini.

\section{REFERENCES}

Cordero del Campillo M., Castañon Ordóñez L. \& Reguera FEO A. Índice-Catálogo de Zooparásitos Ibéricos. Universidade de Leon. Secretariado de Publicaciones. 1994, 650 p.

Moravec F. Studies on the development of the nematode Rhabdochona (Filochona) ergensi Moravec, 1968. Folia Parasitologica, 1972, 19, 321-333.

Moravec F. Reconstruction of the nematode genus Rhabdochona Raillet, 1916 with a review of the species parasitic in fishes of Europe and Asia. Studie CSAV, 1975, 8, 1-104.

Moravec F. Observations on the development of Rhabdochona phoxini Moravec, 1968 (Nematoda: Rhabdochonidae). Folia Parasitologica, 1976, 23, 309-320.

Moravec F. Life history of the nematode Rhabdochona phoxini Moravec, 1968 in the Rokytka Brook, Czechoslovakia. Folia Parasitologica, 1977, 24, 97-105.

Moravec F. Parasitic nematodes of freshwater fishes of Europe. Academia. Prague, 1994, 473 p.
Moravec F. Trichopteran larvae (Insecta) as the intermediate hosts of Rhabdochona bellichi (Nematoda: Rhabdochonidae), a parasite of Barbus barbus (Pisces). Parasitology Research, 1995, 81, 268-270.

Moravec F. \& Scholz T. Life history of the nematode Rhabdochona bellichi, a parasite of the barbel in the Jihlava River, Czech Republic. Journal of Helminthology, 1995, 69, 59-64.

Pereira Bueno J. M. \& Alvarez Pellitero M.P. Rhabdochona spp. en ciprinideos de los rios de León. Anales de la Facultad de Veterinaria de León , 1979, 25, 155-198.

Siegel S. \& CaStellan Jr. N.J. Nonparametric statistics for the Behavioral Sciences. McGraw-Hill Book Company. New York, 1989, 399 p.

Reçu le 19 juin 2001 Accepté le 29 octobre 2001 